\title{
In Pursuit of Public Sector Efficiency and Value Innovation; the Blue Ocean Strategy
}

\author{
Yusheng Kong (Corresponding Author) \\ School of Finance \& Economics, Jiangsu University, China \\ yshkong@ujs.edu.cn \\ Peter Yao Lartey \\ School of Finance \& Economics, Jiangsu University, China \\ efopeter@yahoo.com

\begin{abstract}
Fatoumata Binta Maci Bah
School of Life Science \& Biological Engineering, Jiangsu University, China mariamatimbi@yahoo.com
\end{abstract}

Nirmalya B. Biswas

LSC London, Cardiff Metropolitan University \& ISBC India, India nirmalya.b@isbc.ac.in

Rupa Santosh Jaladi

LSC London, Cardiff Metropolitan University \& ISBC, India rupa.jaladi@gmail.com

Received: Dec. 29, 2017 Accepted: Feb. 26, 2018 Online published: Mar. 7, 2018 doi:10.5296/jpag.v8i1.12781 URL: https://doi.org/10.5296/jpag.v8i1.12781

\begin{abstract}
This paper examines key institutional drivers capable of fashioning an enabling environment for public sector efficiency. The study gathered evidence that institutional variables such as Innovation, Performance orientation, Value Creation and Budget Flexibility are good
\end{abstract}


predictors of public sector efficiency. The extracted variables per the Factor Analysis accounted for $77.3 \%$ variance. Implying that, the 4 extracted factors have significant impact on the dependent variable with relatively high significant alpha value of $p<0.000$, per the multiple regression output, corresponding to relatively positive unstandardized coefficients. This implies that, the explanatory variables are prominent determinants with strong evidence to reject the null hypothesis at $95 \%$ critical value. However, the Adjusted Square R2 indicates a significant relationship between Efficiency and the explanatory variables at $50.3 \%$. The study concluded that, the public sector needs substantial empirical evidence to enlighten the real impact of key institutional drivers of efficiency and a conventional standard for measuring efficiency.

Keywords: efficiency, innovation, blue ocean strategy, performance, technology, public policy

\section{Introduction}

The current economic situation determined by the effects of the crisis is causing the governments of the countries worldwide to streamline their processes in terms of collecting revenue from the state budget and then redistributing it on the principle of performance and economic efficiency (Baumgartner \& Rauter, 2017). In this sense the comparative analysis of the efficiency in the public and private sector is the starting point for studying the role of efficiency, effectiveness and performance regarding the economic governance of resources utilization by the public management for achieving medium and long-term objectives of economic recovery and sustainable development of national economies. Public sector performance represents the objective of this research, aims to quantify and present the real situation in terms of public sector performance in Ghana.

Efficiency is a concept that emerged in recent time and still undergoing major scientific observation by the scientific world. As the world faces challenges of managing global unequal distribution of resources, population increase, and high demands for energy and power, there's a need to do things more efficiently. The term "efficiency" refers to the measure of effectiveness that produces an outcome with the use of minimum time, effort, resource and expertise (Matei \& Drumasu, 2015). A school of thought argued that, the most valuable systems and tools of efficiency is the human effort or labour as a prominent factor of production. If society is truly in pursuit of maximum efficiency, the society must be examined critically towards nurturing the culture of efficiency (van Helden \& Uddin, 2016).

The public sector of Ghana is very vast and arguably the largest employer across all segments. The outcome of decisions and major policies in this sector has a long term implications on the economy as whole. The public sector has contributed immensely through its traditional crucial roles in research and development. That includes heavy investments into projects that set the grounds for the private sector development (Baumgartner \& Rauter, 2017). Traditionally the sector has initiated various research programs aimed at uplifting existing technologies and research programs towards innovation. Though the private sector in recent time has received credit for several initiatives, all indications point to the fact that public sector will surpass the private sector with the vast resources under its command with a more 
positive, practical approach to technology (Adhikari \& Gårseth-Nesbakk, 2016). Logical applications and contemporary techniques are basic requirements for sustainability since the public sector cannot function in today's fast dynamic environment without technical revolution and administrative innovations to shape the work of the public sector.

Various governments in recent time have sought for public sector reforms and efficient management due to increasing advocacy for reforms. Several attempts have been made involving the under-developed and some advanced countries in search of the way forward. However, drawing from the fact that the public sector has come under heavy criticism with respect to efficient institutional functionality as against the private sector where limited resources are applied proficiently for maximum productivity corresponding to stakeholder's interest, The public sector of Ghana is yet to offer such a reward and milestone considering the vast majority forming the stakeholder base (Sour, 2017). Efficiency of state-owned intuitions in Ghana is rated below average performance, thus; according to research. Though, most of the studies singled out fiscal management instead of a holistic approach. Scholars such as (Midin, Joseph, \& Mohamad, 2016), were among the few who focused their studies on efficiency and modernisation and recommended the public sector is completely migrated from the traditional manual processes to digital platforms. The lack of innovation orientation is increasingly contributing to waste of vast resources including foreign aid and grants that goes to needless projects. The situation often spark public debate as to whether majority shares of the public enterprises be privatized in order to secure value ordinary taxpayer. In developed economies ensure the standard of living of the ordinary citizen is guaranteed by efficient management of scares resources by those at the helm of affairs.

\subsection{Theoretical Dimensions}

The concept of value for money and efficiency in the public sector is best defined as a condition where public expectations exceed what governments can offer, therefore creating a big gap between demand and supply of social services and possible disagreement with taxpayers (Matei \& Drumasu, 2015) A countless events may account for conditions that could limit an organisation from achieving efficiency. - Irrespective of whether private or public sector - as well as disrupt its smooth performance and efficiency of activities (Ashraf \& Uddin, 2016). Possible cause of decline in efficiency in public sector is dealt with in Sun Tzu's 'The Art of War', written and published 2,500 years ago but still teaches great deal of lessons in management practices related to resources, time and people to deliver efficiency (Elbanna, 2016). The concept talks about capacity building, team work and knowledge management aspect of efficiency which is possibly a vital concept to advance efficiency in any organisation not only the public sector. There are set of prominent guides contained in the 'Art of war' thus; commitment, integrity, accountability and teamwork at both employees and leadership levels, meaning if the organisation is determined to achieve efficiency, a collective effort is required to meet all the criteria above (Ashraf \& Uddin, 2016). This implies that, in an event where public sector employees are exempted from taking part in major policies about their work, they will certainly be inefficient. The concept of value for money begun in the public sector, about 320 years ago in something called the National Order Office of the UK Government. Its job was to make sure the taxpayer's money is protected, and not only 
protected in terms of not being stolen but protected in the sense that, it is put into proper use. This implies that the taxpayers hold a share in the affairs of the public sector regarding how wise their money is been used (Scupola \& Zanfei, 2016). The blue ocean concept cuts across all decision making levels in an organisation thus; corporate level, middle level and the business level where actual implementation of policies take place (Jones and Wicks, 1999). The concept established that efficiency and innovation occurs when relatively fewer resources are utilised to maximum satisfaction at relatively low cost. According to literature, the concept of Blue Ocean is widely applied in the private sector where corporate organisations compete for profit and superiority in the industry (Arundel, Casali, \& Hollanders, 2015). This paper attempts to apply the blue ocean strategy to the public sector where innovation and efficient and judicious management of scares resources is much required. According to Elbanna (2016), the stakeholders theory supports the idea of adequately fulfilling the interests of the entities associated in the affairs of an organisation; it includes those who have contributed to the running the organisation directly or indirectly. A famous strategy scholar, Freeman, describes stakeholders as persons who for a good reason are concerned willingly or as an obligation towards the operations of an institution (Freeman, 1994).

\section{Literature review}

\subsection{Public Sector Efficiency}

The public-private sector comparison debate on the bases of efficiency and innovation requires a collective effort by all stakeholders to address the extent of waste occurring in various institutions within the sector. Evidence from practical viewpoint indicates the private sector is more efficient in terms of managing resources. However, few experts hold a contrary view to this claim (Blok, Wesselink, Studynka, \& Kemp, 2015). These group of intellectuals believe that the public sector being the largest employer across the length and breadth of the country is faced with numerous challenges compared to their counterparts in the private sector who employs just a fraction of the working class therefore are faced with less challenges and responsibilities. According to (Joyce, 2015), the public sector commands vast resources and revenue that it generates couple with the tax base accruing to government placing the sector far ahead of the private sector when we talk of the means to acquire the best innovative and technologically advanced methods to increase productivity, check waste of resources , time keeping and suitable reward for outstanding performance .

Major stakeholders have argued over privatisation of underperforming public institutions if not all. Others still hold the view that innovation and reforms couple with technology could turn things around (Cohen, 2015). Technically, many are not in favour of what seem to be a hostile privatisation of publicly owned enterprises. There is substantial evidence that those in support of the argument to privatise some public companies are attributed to non-satisfactory management (Sutheewasinnon, Hoque, \& Nyamori, 2016). First of all, the argument for privatisation and the use of private sector expertise is most often misconstrued. Most often than not its due to efficient cost and material management for quality and maximum productivity (De Magalhães \& Freire Trigo, 2017). Some experts in the public sector believe 
the private enterprises are no more efficient in technical abilities but very innovative in taking advantages of every economic conditions that falls within their domain whether positive or negative. That is the essence of innovation, changing the outcome of a threat within a hostile business environment into a lucrative business opportunity and the ability to sustain the position to create value for the end user at minimal cost. This is the degree of innovation the public sector is lacking (Balabonienė \& Večerskienè, 2015), However, Maresova and Kacetl (2015), are of the view that privatisation ceases to be a growth strategy for the public sector due to influx of foreign donor support for state institutions and a few public -private partner initiatives to leverage technical and managerial issues facing the public sector (Aziz, Rahman, Alam, \& Said, 2015). This is because privatisations in practical sense are a disadvantage to the public considering the marginal proportion of income generated that goes to government and relatively larger share that goes the private partners (Córdova, Durán, \& Galindo, 2014). The situation is so because the public organisations lack innovation to keep pace with the private sector that spend their scare resources to ensure the implementation of suitable corporate strategies that will impact the long term success.

The biggest single disadvantage is that the cost of investment in privatised companies are nearly always significantly more expensive especially is majority are controlled by outsiders and under private operators management, because higher profits are guaranteed in addition to quality output (Alzeban \& Gwilliam, 2014).This implies that, the private sector focuses of quality rather than quality but very expensive especially if they are to purchase a highly sophisticated technology to enable them perform their duties (De Bruecker, Van den Bergh, Beliën, \& Demeulemeester, 2015). Comparing the cost of innovation and privatising public organisations for the sake of efficient management, several opinion leaders have shared their thoughts and concluded that the public sector must rather adapt innovation, create value and deliver on the needs of the citizens at moderate cost while efforts are made to reduce waste of public resources and irregularities that has taken over the public sector financial management (ter Bogt \& Tillema, 2016).

The recently conducted survey to compare efficiency between the public and the private enterprises indicted that private companies remained efficient only on cost management and quality of output or satisfactory delivery of service but failed on several parameters such as the need to cater the human resource that is being employed under unfavourable working conditions and unsatisfactory rewards (Kromidha \& Córdoba-Pachón, 2017). However, similar studies conducted among a couple of European companies that were privatised between 1980 to 2008 performed poorly according to the study by Joseph Stieglitz, a Nobel prize winner in 2013 (Omar, Weerakkody, \& Sivarajah, 2017). The study was a comprehensive analysis of successful companies compared to their unsuccessful counterparts during the periods of privatisation and after privatisation. The study concluded that out of every teen (10) companies that were privatised six were previously performing above average and was properly managed with cost under control therefore the privatisation strategy had no impact on their future prospects (Weerakkody, Omar, El-Haddadeh, \& Al-Busaidy, 2016). A classical example is Russia where the periods of privatisation for almost 10 years caused a drastic decline in the national income and GDP indicating that privatization did not improve 
performance. However, in the case of Ghana several states owned enterprises that were privatised contributed efficiently to national output. Some examples are the Cocoa processing company and The Ghana Telecom Company currently managed by private partners is earning record high profits, than the previous management (Elbanna, 2016). Drawing form the above study, if it is evident that the private companies are applying innovation and are being efficient in managing cost, human resources, competitive market and hostile economic environment, then the public sector with vast resources has no justification to continue to waste its scarce resources simply because the resources does not belong to a single individual.

\subsection{Blue Ocean Strategy}

In times when citizens and transparency advocates are championing the course for public sector efficiency, it requires a pre-emptive strategic choice to eliminate waste and inefficiency in the public sector specifically at the local government level which is one institution that deals directly with the concerns of the general public (Chan Kim \& Mauborgne, 2005). The benefits of the model are to embrace factors that can transform the entire sector towards value creation.

\section{Traditional companies}

Blue Ocean Companies

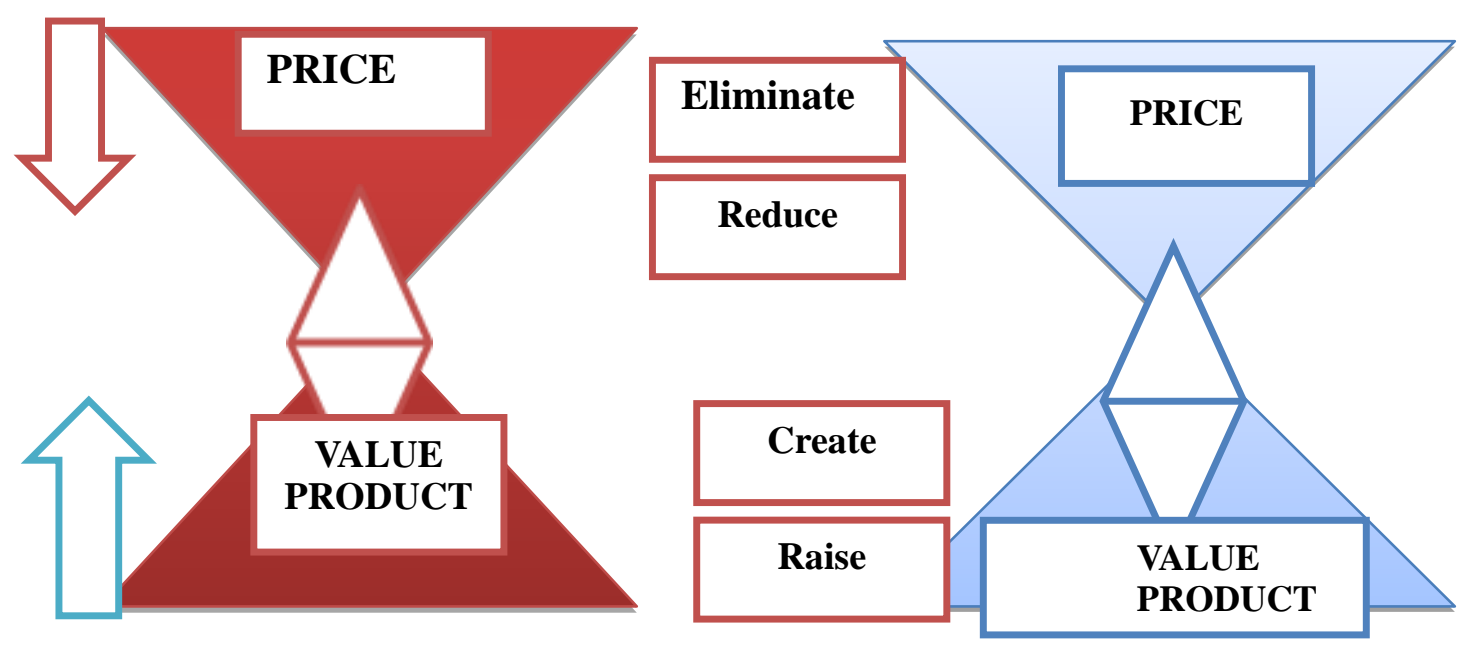

Figure 1. Value innovation: Adopted from: (Chan Kim \& Mauborgne, 2005)

The blue ocean strategy concept has received much attention in strategic management literature over the years. However, the concept is yet to witness its full potential in the public sector.In order to contribute to knowledge, this study sought to explore the aspects of blue ocean capable of reinventing innovation on various parameters of the model (Chan Kim \& Mauborgne, 2005). The Blue ocean strategy was propounded by two professors from INSEAD in France in the year 2005. The two professors; (W. Chan Kim and Renne Mauborgne) became famous for developing strategic concepts base on the following:

a. How to create uncontested market space by reconstructing a market boundaries 


\section{Macrothink}

b. Focus on the bigger picture

c. Innovation

d. Go beyond the traditional customers.

e. Create an uncontested market.

f. Getting the strategic sequence right.

Blue Ocean Strategy (BOS) is the result of 20 years of research into over 150 strategic moves made between 1880 and 2000 in more than 100 leading companies from 30 different industries. All of these companies have successfully created new markets with innovative products, services and entire new business models (Azar, 2008). Theoretically, Blue Ocean Strategy was introduced to inculcate creativity, innovation, and out-of-the-box thinking in coming up with methods to help enhance people's lifestyle with minimum costs (Cardy \& Selvarajan, 2006). Though the strategy is widely applied in business, few advance countries have adopted the concept and have since recorded positive outcomes in value creation and efficient public sector management (Kim \& Mauborgne, 2009). The Malaysian government adopted the concept and made it a part of their national strategic plan. The strategy has since been applied fully to its full potential in Malaysia since 2010. It was named as the National Blue Ocean strategy (NBOS) (Kim \& Mauborgne, 2009). The model is clear on distinguishing the factors that promote efficiency and innovation and those that kill positive initiatives and potentials

The Blue Ocean strategy

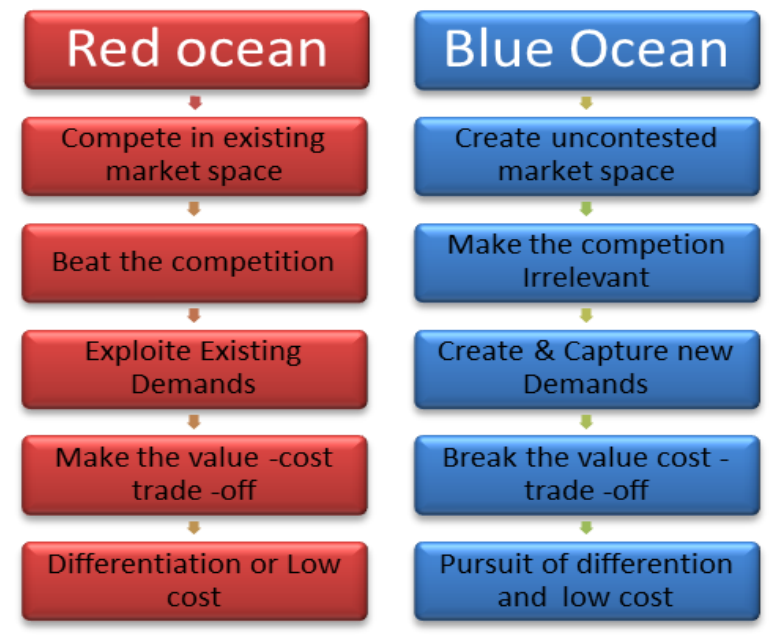

Figure 2. Blue ocean assumptions adopted from: (Chan Kim \& Mauborgne, 2005)

The concept has been applied extensively as cost reduction strategy and maximizing output in most advanced countries. It was reported that it gave a remarkable benefits to society and governments such as Russia and Malaysia (Azar, 2008). This paper seeks to advocate for the model and its application in the public sector, hence the motivation behind the study. The model and the assumptions have gone under several review and consistent evaluation to suit the current business dynamics and trends (Chan Kim \& Mauborgne, 2005). In line with the 
above previous application, this paper is focused on examining its impact on the public sector of Ghana based on the strategic moves established by the two professors Kim and Mauborgne.

\subsection{Public Sector Value Innovation}

Innovation can be termed as the generation and application of new ideas. However its application in the private sector is much easier because in the private sector, the competitive drivers lead companies to really appreciate innovation as a means of creating and improving services, product features and quality which evenly results in profits. (Sour, 2017). Although in the private sector the key drivers are different, there is evidence of efforts directed towards innovation as a means of improving productivity and efficiency (Cardy \& Selvarajan, 2006). According to a school of thought, the innovation process in the public sector is quite different. This is because, opportunities and risks are very challenging within the public sector comparing to the private sector. That notwithstanding, innovation is important in the sustainability of the public sector due to the size, according to (Elbanna, 2016). A fractional improvement in productivity in the public sector can make contribute a huge percentage of the GDP of a country, therefore size matters. Currently, economies are evolving and the world is changing rapidly, therefore the public sector needs to come out with new policies to make up with the rapid transitions of the global economy (Joyce, 2015)

Therefore, it is not only the private sector that innovates, the public sector entities equally embrace innovation by seeking to apply non-traditional approach with the aim of serving the public satisfactorily. The sector of Ghana comprises all state corporations and the central government functionaries including the local government levels (Joyce, 2015). The public sector render social service such as administration, peace and security, safety and healthcare and education. To a large extent the sector is responsible for setting a favourable and regulated business environment for the citizenry.

As theory and practice have it, innovation in the public sector can occur at various administrative structures and procedures or the kind of service that are being offered based on a particular policy direction (Farzin, Kahreh, Hesan, \& Khalouei, 2014). The public sector is a major economic driver, accounting for over $75 \%$ of the Gross Domestic product. The percentage of public sector expenditure stands at 60\% each year. As of end 2016, public expenditure across Denmark, Finland, France, Sweden stood at 55\% while America recorded $40 \%$. In recent time the sector is encountering aggregate demands from a rapidly increasing population with complex needs. The central government that controls the public sector is expected to manage challenges such as climate change, unemployment and healthcare from a very tight fiscal budget each year (Farzin et al., 2014).

This has necessitated operating a cost effective but efficient approach to delivering social services at relatively lower cost. Many countries including Ghana have seen the need to integrate innovation as an important ingredient to driving any social development Cardy and Selvarajan (2006). According to (Gursoy \& Swanger, 2007) a simple way of driving innovation could take three forms, thus; improve accessibility to social services by means of exploring digital platforms and expanding current physical structures. He added that, 
engaging the end users of these service is a form of innovation and it lessens the burden on service providers as communities, organisations and individuals are integrated into various part of the supply chain, even with the help of the private sector in case of outsourcing. Finally, delivery of specific user needs to particular groups accurately may amount to innovation. In this scenario, services are tailored more adaptably to meet citizen's needs, while public procedures and communications are being adapted to address feedbacks from users.(Kim \& Mauborgne, 2009). Drawing from literature, there are concerns about the current waste of public funds and resources, while a section of authorities thinks government approach to innovation is much to be desired considering a $70 \%$ of national budget that goes into procurement of goods and services for the ministries and departments (Yapa, 2014). Incurring such a huge percentage of expenditure on procurement requires an innovative approach to either reduce cost and expenditures that are not adding value. Channel investment towards. This paper is drawing inspiration from countries like United State of America, China and some part of Europe where innovation is being applied on full scale with positive outcomes (Matei \& Drumasu, 2015).

\subsection{Strategic Management}

It is prudent to first of all give a brief explanation on the concept of strategic management before taking a comprehensive look at the concept and application of the blue ocean strategy. According to ("Strategic management: Fred R. David, Prentice-Hall (1995), 5th Edn, 1084 pp., £21.95," 1995) the term "strategy" simply stands for an organisation's preparedness in terms of resources and capabilities backed by plans to pursue their long term objectives whether sustainability, survival is a highly competitive environment with the aim of creating a high competitive advantage (Kromidha \& Córdoba-Pachón, 2017). Some authors relate strategic management to maintaining organisational efficiency in terms of quality service delivery and base on that for a competitive advantage while a leading author in strategic literature Fred David also relate strategy to managing the entire organisational performance with the aim of outperforming competitors either by basing on the organisational internal resources or deploying the best business or corporate level strategies suitable for gaining a high value and competitive advantage (Lapsley \& Rekers, 2017). This means strategy is a systematic process depicted by the model below;

\section{Strategic management Process}

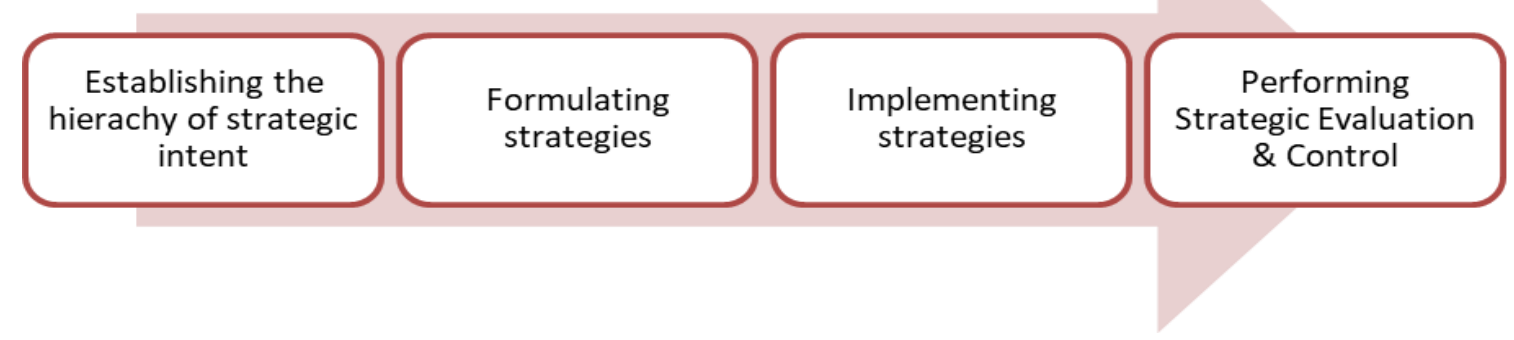

Figure 3. ("Strategic management: Fred R. David, Prentice-Hall (1995), 5th Edn, 1084 pp., $£ 21.95, " 1995)$ 


\section{Macrothink}

Journal of Public Administration and Governance ISSN 2161-7104 2018, Vol. 8, No. 1

The fundamental principle is trying to be efficient than competitors with the best approaches at the right time after doing a thorough internal and external analysis to determine the position in terms its finances, expertise, technological and resource capabilities. In terms of the public sector, policies makers may have to critically exams the best options that will better the living conditions of the citizenry, as they are being served across various segments. Though, there are few arguments regarding whether strategy starts after planning or vice versa, the relevance of strategic management remain prominent in contemporary business despite the fact that, not all successful companies align themselves with scientific approach to management (Balabonienè \& Večerskienè, 2015). That notwithstanding, the relevance of strategic management, for that matter blue ocean cannot be over emphasized. Evidence from leading authors in strategic management have advocated for innovative approach to management by working towards reducing irrelevant cost implications and avoidable constraints and redirect resources to value for money schemes. In the case of business enterprises, they may have to eliminate competition through innovation as prescribed by the blue ocean and Jim Collins (Boe \& Kvalvik, 2015). A contrary opinion from Philip Kotler and Michel Porter emphasized on the importance of sustainability in the business by effectively competing and managing the forces that are controlling the industry (Ozkan-Tektas \& Basgoze, 2017). Drawing from the above views it seem to suggest that strategy is matter of operational efficiency and effectiveness and benchmarking performance above industry and rivals in either an existing market or newly discovered market (Ahmed \& Rafiq, 2002). As it is arguably acceptable that the public sector service delivery is not mainly about competition, the focal point of attaining efficiency here will be to generate new ideas and delivering accurately on social needs.

\section{Conceptual Framework}

The conceptual framework depicts four independent variables capable of influencing efficiency in public sector management across all sectors. Technology, Value creation, Orientation and budget Flexibility are set to rejuvenate the current level of efficiency.Innovation serves as a mediating factor. The unit will serve as a transition point of any efficient strategy from the independent variables leading to efficiency

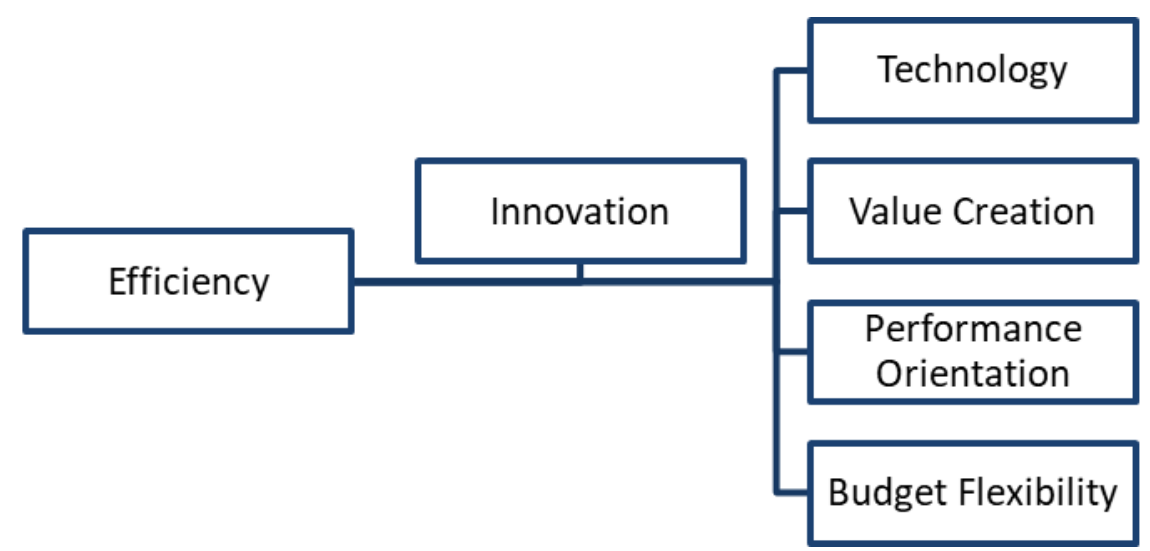

Figure 4. The generic framework guiding the study

Source: by Authors (Adopted based on Literature) 


\section{The Study Design}

The study focused on exploring the determinants of efficiancy in the public sector, Ghana. The sample comprised of 250 repondents from public agencies and departments located in Accra and supervised by the central governement. However, only 5 ministries qualified for the study through purposive sampling. Structured questionaire drafted on a 5 likert sacale were administered for data gathering. The study deplaoyed Factor Anlysis and Principal component to examine the explanatory variables to be considered for a regression analysis, by assuming the Eigenvalues with the highest \% of variance explaining the significance. Drawing lessons from (Remmers et al.,1974;Cessar and Holmes,2004), we classified Efficiency (EFY) under dependent variable, while Technology (TCH), Innovation (INV), Performance orientation (POR), Budget Flexibility (BDG) and Value creation (VCR) respectively fall under independent variables capable of driving efficiency. Data captured and grouped under each variable is a truly describes public opinion (Myers, 1985).

The model and Variable Definitions

The generally accepted multiple regression model is given as follows ;

$Y i=\beta 0+\beta 1 x i+\varepsilon i$

$\mathrm{Y}_{\mathrm{i}}=$ Dependent variable being Efficiency $(\mathrm{EFY})$

$\beta_{0=\text { Population }} \mathrm{Y}$, intercept

$\beta_{1=\text { Population Slope }}$ coefficient $\left(\beta_{1 \ldots . .} \beta_{5}\right)$

$\mathrm{X}_{\mathrm{i}=\text { Independent variables }}(\mathrm{TECH}, \mathrm{INV}, \mathrm{POR}, \mathrm{BDG}, \mathrm{VCR})$

$\mathrm{Ei}=$ Random error term

From the equation, i stands for the unit of measurement. The left part of the equation represents the dependent variable Yi indicting efficiency. The independent variables are represented by xi which remains constant, while the random error term is denoted by $\mathcal{E}$. If a represent a consistent parten, the lenear regression model is likely to offer an accruate forecast and estimate of a and b. In order to explore the relationship between Efficiency and the independent variables the analysis will follow this format;

$$
\mathrm{EFYi}=\beta \mathrm{o}+\beta 1 \mathrm{TCHi}+\beta 2 \mathrm{INVi}+\beta 3+\mathrm{PORi}+\beta 4 \mathrm{BFL} \mathrm{i}+\beta 5 \mathrm{VCTi}+\varepsilon \mathrm{i}
$$

\subsection{Relaibility Statistics (Cronbach's Alpha)}

Cronbach's alpha can be written as a function of the number of test items and the average inter-correlation among the items. The standardized Cronbach's alpha can written as :

Cronbach's Alpha

$$
\alpha=\frac{N . C}{V+(N-1) \cdot C}
$$

Cronbach's Alpha is considered to be a measure of scale reliability. A "high" value for alpha does not imply that the measure is uni-dimensional. However, the researcher sought to 
measure the reliability based on the 0.7 threshold in order to confirm the internal consistency for a reliable exploratory factor analysis on the six constructs

Table 1. Showing the acceptable of the Cronbach's Alpha values

\begin{tabular}{l|l|l}
\hline Constructs & Cronbach's Alpha & N of Items \\
\hline Technology( Tech) & 0.834 & 5 \\
\hline Innovation (INV) & 0.822 & 5 \\
\hline Performance(PO) & 0.802 & 5 \\
\hline Budget Flex (BDG) & 0.813 & 5 \\
\hline Value Cretion(VCR) & 0.842 & 5 \\
\hline Efficiency(EFY) & 0.812 & 5 \\
\hline
\end{tabular}

Source :( Author's computation) Cronbach's Alpha calculations.

The reliability test table above is an indicator of a high consistency in the data captured for this study. It confirms that all the six (6) constructs have a reliability coefficient of $70 \%$ which is acceptable in social science research.This makes it convinient for factor analysis and principal component to be to determine the dominant constructs

\section{Descriptive Statistics}

\subsection{Factor Analysis}

The study adopted Factor analysis as one the widely used statistical technique to describe variability among observed correlated variables in terms of a potentially lower number of unobserved variables called factors. The principal components are meant to extract the explanatory variables with acceptable eigenvalues.

Principal Components

Table 2. Principal Component matrix showing the extracted constructs with eigenvalues greater than 1

\begin{tabular}{|c|c|c|c|c|c|c|c|c|c|c|}
\hline & \multirow[b]{2}{*}{ Component } & \multicolumn{3}{|c|}{ Initial Eigenvalues $^{\mathrm{a}}$} & \multicolumn{3}{|c|}{$\begin{array}{l}\text { Extraction Sums of Squared } \\
\text { Loadings }\end{array}$} & \multicolumn{3}{|c|}{$\begin{array}{l}\text { Rotation Sums of Squared } \\
\text { Loadings } \\
\end{array}$} \\
\hline & & Total & $\begin{array}{c}\% \text { of } \\
\text { Variance }\end{array}$ & $\begin{array}{c}\text { Cumulative } \\
\%\end{array}$ & Total & $\begin{array}{c}\% \text { of } \\
\text { Variance }\end{array}$ & $\begin{array}{c}\text { Cumulative } \\
\%\end{array}$ & Total & $\begin{array}{c}\% \text { of } \\
\text { Variance }\end{array}$ & $\begin{array}{c}\text { Cumulative } \\
\%\end{array}$ \\
\hline \multirow[t]{6}{*}{ Raw } & 1 & 10.789 & 21.921 & 21.921 & 10.789 & 21.921 & 21.921 & 8.765 & 17.809 & 17.809 \\
\hline & 2 & 10.094 & 20.510 & 42.431 & 10.094 & 20.510 & 42.431 & 10.041 & 20.401 & 38.210 \\
\hline & 3 & 8.820 & 17.921 & 60.352 & 8.820 & 17.921 & 60.352 & 10.265 & 20.856 & 59.066 \\
\hline & 4 & 8.347 & 16.960 & 77.312 & 8.347 & 16.960 & 77.312 & 8.980 & 18.246 & 77.312 \\
\hline & 5 & 6.729 & 13.673 & 90.985 & & & & & & \\
\hline & 6 & 4.437 & 9.015 & 100.000 & & & & & & \\
\hline \multirow[t]{6}{*}{ Rescaled } & 1 & 10.789 & 21.921 & 21.921 & 1.143 & 19.058 & 19.058 & 1.226 & 20.438 & 20.438 \\
\hline & 2 & 10.094 & 20.510 & 42.431 & 1.122 & 18.703 & 37.761 & 1.104 & 18.404 & 38.842 \\
\hline & 3 & 8.820 & 17.921 & 60.352 & 1.092 & 18.196 & 55.957 & 1.050 & 17.505 & 56.347 \\
\hline & 4 & 8.347 & 16.960 & 77.312 & 1.045 & 17.420 & 73.377 & 1.022 & 17.030 & 73.377 \\
\hline & 5 & 6.729 & 13.673 & 90.985 & & & & & & \\
\hline & 6 & 4.437 & 9.015 & 100.000 & & & & & & \\
\hline
\end{tabular}

Extraction Method: Principal Component Analysis. 


\section{Macrothink}

a. When analyzing a covariance matrix, the initial eigenvalues are the same across the raw and rescaled solution.

\section{Explanatory Variables}

There are 4 extracted constructs explaining variations in the principal component analysis above. The commulative eigenvalue corresponds to $77 \%$, slightly below the $90 \%$ threshold. However, Innovation (INV) being the first contruct explains $21.9 \%$ of variations. Budget Flexibility (BDG), Performamnce Orientation (PO) and Value Creation (VCR) have relatively higher eigenvalues greater than 1.0 and lie above 1.0 on the scree plot below. By implication, we apply the Kaiser rule to eliminate all the contrsucts with eigenvalues less than 1.0. This being the eigenvalue equal to the variation explained by an avaryage single construct. Going by the Kaiser critaruim we retain the 4 components with (21.921), (20.510), (17.921), and (16.960) eigenvalues representing the factors which have the entire confidence interval greater than 1.0 per the extraction method.

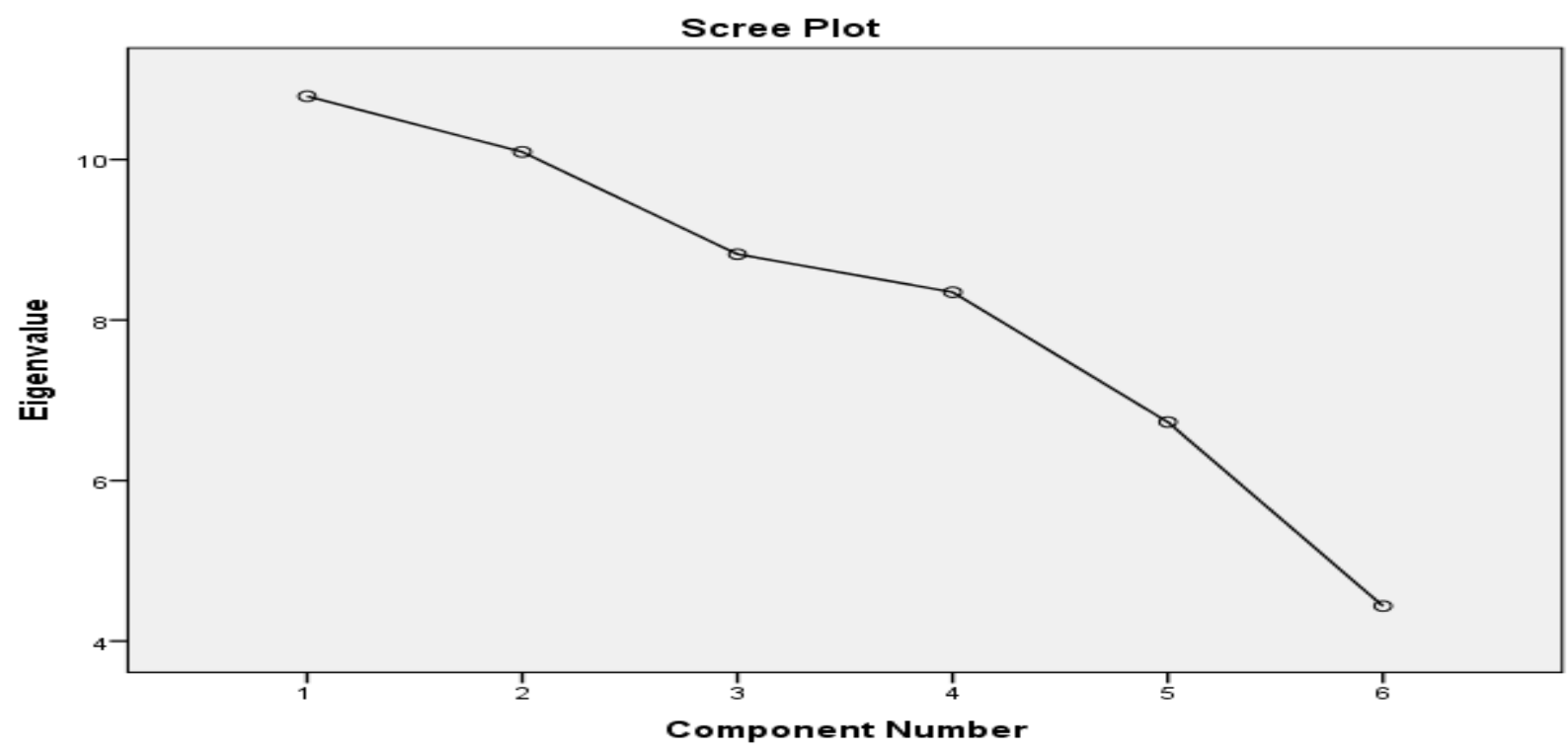

Figure 5. Depicting the Scree Plot of Extracted variables above 1.0

The plot depicts the 4 factors with eigenvalues higher than 1.0. Mapping the $\mathrm{x}$-axis to the $y$-axis, the 4 spots along the curve corresponds to component number 4 on the $x$-axis indicating the cut-off point for the less explanatory variables to be dropped.

\section{KMO and Bartlett's Test.}

Table 3. Shows the KMO and Bartlett's goodness fit Test

Kaiser-Meyer-Olkin Measure of Sampling Adequacy. 
Source: (Author's computation)

The KMO sampling test for adequacy further confirms the reliability and robustness of the sample dennoted by 0.791 which is above the 0.5 acceptable perimeter. Bartlett's Test of sphericity also confirms that the metrices meet all necessary requirements to be factored. It also implies that the factor analysis conducted above meets the criteria for further statistical analysis to be performed.

\subsubsection{Result and Implication}

In measuring the degree of variance by the independent variables (explanatory variables ) on the dependent variable, a regression analysis is suitable, following the outcome of the Factor analysis performed, to further confirm the variations explained in the principal component analysis.

\section{Regreession Analysis}

The multiple regression output depicts a statistically significant p-value of 0.000 , implying that the model is fully fit and also fulfilling the critital value of 0.05 alpha requirement. The highly significant alpha value also demonstrate how good the independent variables can predict or influence the dependent variable with a strong evidence to reject the null hypothesis.

Table 4. Indicting the Regression result.

Model Summaryb

\begin{tabular}{|c|c|c|c|c|c|c|c|c|c|c|}
\hline \multirow[b]{2}{*}{ Model } & \multirow[b]{2}{*}{$\mathrm{R}$} & \multirow[b]{2}{*}{$\begin{array}{c}\mathrm{R} \\
\text { Square } \\
\end{array}$} & \multirow[b]{2}{*}{$\begin{array}{c}\text { Adjusted R } \\
\text { Square } \\
\end{array}$} & \multirow[b]{2}{*}{$\begin{array}{l}\text { Std. Error of } \\
\text { the Estimate }\end{array}$} & \multicolumn{5}{|c|}{ Change Statistics } & \multirow[b]{2}{*}{ Durbin-Watson } \\
\hline & & & & & $\begin{array}{c}\text { R Square } \\
\text { Change }\end{array}$ & $\begin{array}{c}\mathrm{F} \\
\text { Change }\end{array}$ & df1 & df2 & $\begin{array}{l}\text { Sig. F } \\
\text { Change }\end{array}$ & \\
\hline 1 & $.715^{\mathrm{a}}$ & .511 & .503 & 4.71895 & .511 & 63.967 & 4 & 245 & .000 & .229 \\
\hline
\end{tabular}

a. Predictors: (Constant), ValueCre, Innovation, BudgetF, Perform

b. Dependent Variable: Efficiency

Source (Author's computation)

The degree of variance explained by the total predicting variables is 0.503 per the Adjusted $\mathrm{R}$ Square, implying that $50.3 \%$ of variation can be explained by the 4 predicting variables. The $\mathrm{R}$ Square of $51.1 \%$ is slightly above the Adjusted R Square, also implies that Efficiency in the public sector can be influenced by the 4 independent variables however at a moderate level but with a high confidence internal of 0.000 . The model predicted that, the dependent variable (Efficiency $-\mathrm{Y}_{\mathrm{i}}$ ) will improve by $50.3 \%$ if an extra dollar is invested into the public sector to enhance the four explanatory variables.

\section{ANOVA - Analysis of Variance}

The ANOVA table statistically, is meant to determine whether or not the model is significant, 
in other words whether the independent variables are good predictors with low or high impact in explaining the dependent variable. In this case the ANOVA table below has a significant level of $p<0.000$ which is less than $p<0.5$ alpha value. It however confirms that, the Innovation, Budget flexibility, Performance Orientation and Value creation are statistically good determinants of public sector efficiency.

Table 5. Shows the Analysis of Variance output result.

ANOVAa

\begin{tabular}{rl|r|r|r|r|r}
\hline Model & & Sum of Squares & df & Mean Square & \multicolumn{1}{c|}{ F } & \multicolumn{1}{c}{ Sig. } \\
\hline 1 & Regression & 5697.763 & 4 & 1424.441 & 63.967 & $.000^{\mathrm{b}}$ \\
& Residual & 5455.773 & 245 & 22.268 & & \\
& Total & 11153.536 & 249 & & & \\
\hline
\end{tabular}

a. Dependent Variable: Efficiency

b. Predictors: (Constant), ValueCre, Innovation, BudgetF, Perform

\section{Regression Coefficients}

At $95 \%$ confidence interval, Innovation has a statistically significant impact on the outcome variable being Efficiency. The significance level in total represents a highly positive influence on the dependent variable. The unstandardized coefficient for innovation has a value of 0.037 meaning that a unit change in investment or any change towards innovation in the public sector is associated with $3.7 \%$ increase in Efficiency which is quite satisfactory statically. Budget Flexibility and Value creation both have a relatively high unstandardized coefficient values of 0.808 and 0.056 respectively however with a relatively less significant $p$ value of 0.002 and 0.010 although it still fall below the 0.5 requirement.

Table 6. Showing the coefficients of the explanatory variables Coefficientsa

\begin{tabular}{|c|c|c|c|c|c|c|c|c|}
\hline & & \multicolumn{2}{|c|}{$\begin{array}{c}\text { Unstandardized } \\
\text { Coefficients } \\
\end{array}$} & \multirow{2}{*}{$\begin{array}{c}\text { Standardized } \\
\text { Coefficients } \\
\text { Beta } \\
\end{array}$} & \multirow[b]{2}{*}{$\mathrm{t}$} & \multirow[b]{2}{*}{ Sig. } & \multicolumn{2}{|c|}{$\begin{array}{l}95.0 \% \text { Confidence Interval } \\
\text { for B } \\
\end{array}$} \\
\hline \multicolumn{2}{|c|}{ Model } & $\mathrm{B}$ & Std. Error & & & & $\begin{array}{l}\text { Lower } \\
\text { Bound }\end{array}$ & $\begin{array}{l}\text { Upper } \\
\text { Bound }\end{array}$ \\
\hline \multirow[t]{5}{*}{1} & (Constant) & 5.225 & 1.013 & & 5.157 & .000 & 3.229 & 7.220 \\
\hline & Innovation & .037 & .078 & .034 & 475 & .000 & 191 & .117 \\
\hline & Perform & .024 & .376 & .022 & .064 & .000 & 716 & .764 \\
\hline & BudgetF & .808 & .257 & .770 & 3.139 & .002 & .301 & 1.315 \\
\hline & ValueCre & 056 & .397 & .052 & .141 & .010 & 238 & .726 \\
\hline
\end{tabular}

Dependent Variable: Efficiency

The coefficient table displays positive beta for all independent variables, implying that any unit increase or additional input by the public sector to improve innovation, performance, Budget and expenditure applications and investment in projects that will add value to the 
public sector performance and efficiecy, there will be more than $77 \%$ inreamenent in efficiency per the standardized beta corresponding to Budget Flexibility.

\section{Conclusion}

The research gap we sought to fill is based on the possibility of an alternative approach to delivering efficient public services to the ordinary citizens and commitment in utilizing the available scarce resources for maximum output. Our study shows that, despite the increased relevance of technology in management, its application in the day-to -day activities among the selected public sector organisations in Ghana is quite marginal and the effect on efficiency is immaterial. On a broader perspective, when we compare the significant public sector efficiency in certain countries such as, South Korea and Malaysia who gained independence on the same day with Ghana we seee a vast differece due their commitment to pursuit public sector efficiency by making innovation a national policy.

We also find that, the sector public is confronted with the absence of innovative leadership. In the sense that, in many cases lack of budget supporting innovative schemes and lack of incentive package to inspire innovative initiatives account for inefficiencies and waste in the use of public resources. As a result, the sector is experiencing a slow transformation.We therefore agree with an earlier study by (Joyce, 2015), who suggested a national blueprint to guide public innovation schemes instead of been resilient to change.

This study is consistent with a related research in Tanzania by (Yapa, 2014), where public sector inefficiency is attributed to organisations independently targeting reforms perculier to their domain in an attempt to address institutional deficiencies instead of modifying budgetary policies by implementing a budgeting system that focuses on result -oriented approach to management. In response, the system will deliberately promote inter-organisational competition to inspire quality service delivery from individual agencies discharging such social services. Identifying the key drivers of change is relevant to reaching a comprehensive assessment and measuring performance against standard, which are critical aspects of performance orientaion.

\subsection{Recommendations}

Application of Blue Ocean Strategy

The outcome of the study requires a strategic direction to address the challenges confronting the public sector. It's worthy to draw lessons from previous cases outlined by the pioneers of the blue ocean strategy. Value creation was seen in the case of Southwest Airlines, Hewlett-Parkard (HP) who applied innovation to overcome organisational hurdles by adopting the cost leadership strategy and performing above their industry standards. 


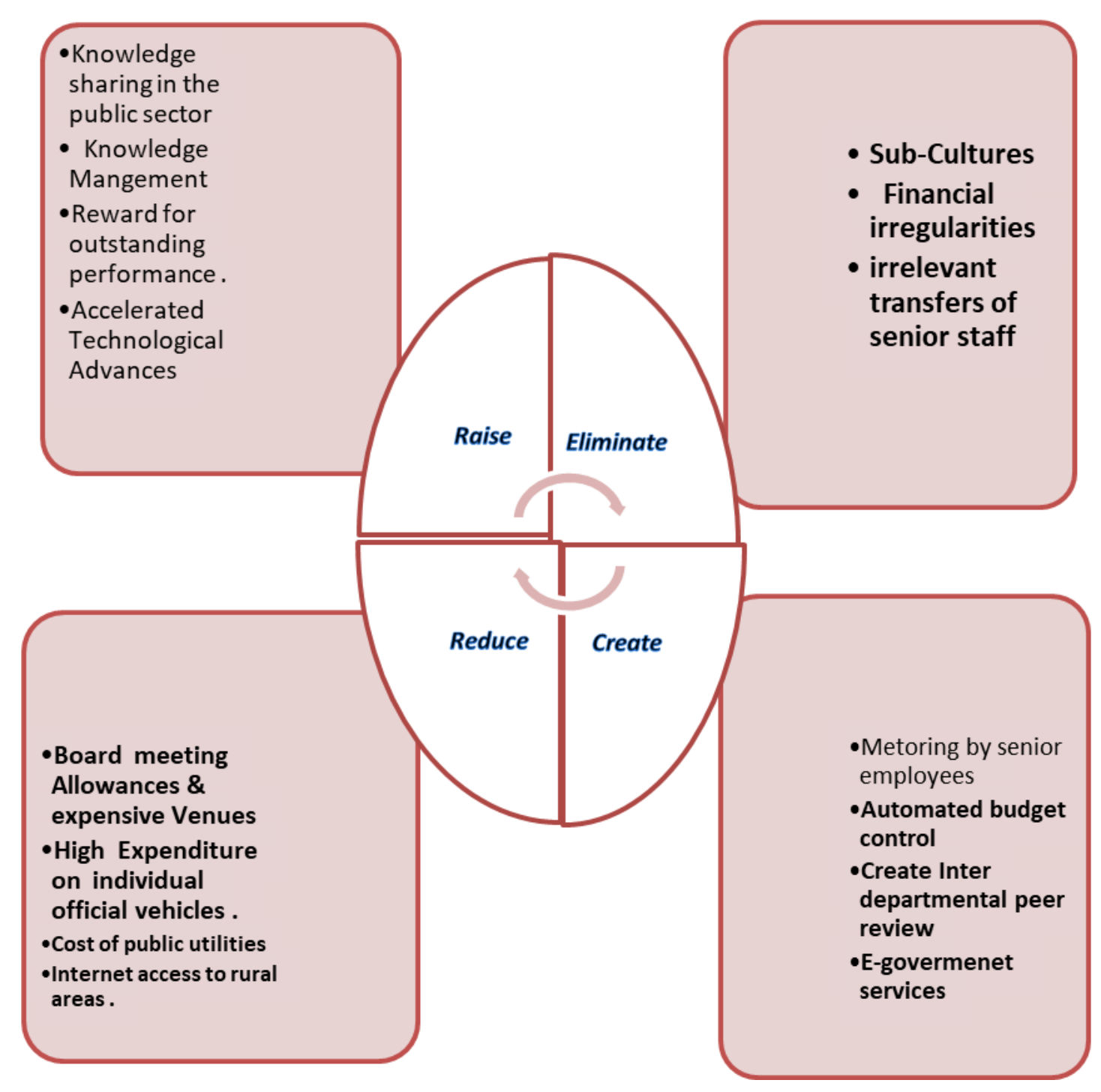

Figure 6. Four Action Frameworks

Source :(Kim \& Mauborgne, 2009)

\section{Value innovation}

The Four Action framework is based on literature and theory underpinning the critical success factors the study identified and categorized under; raised, reduced, eliminated and create to ensure management efficiency and innovation. The framework is designed bases the parameters prescribed by Chan Kim and Mauborgne (2005) indicating the strategic approach to achieve value innovation as illustrated in table figure. 6 . 


\section{Blue Ocean Strategy Canvas}

6

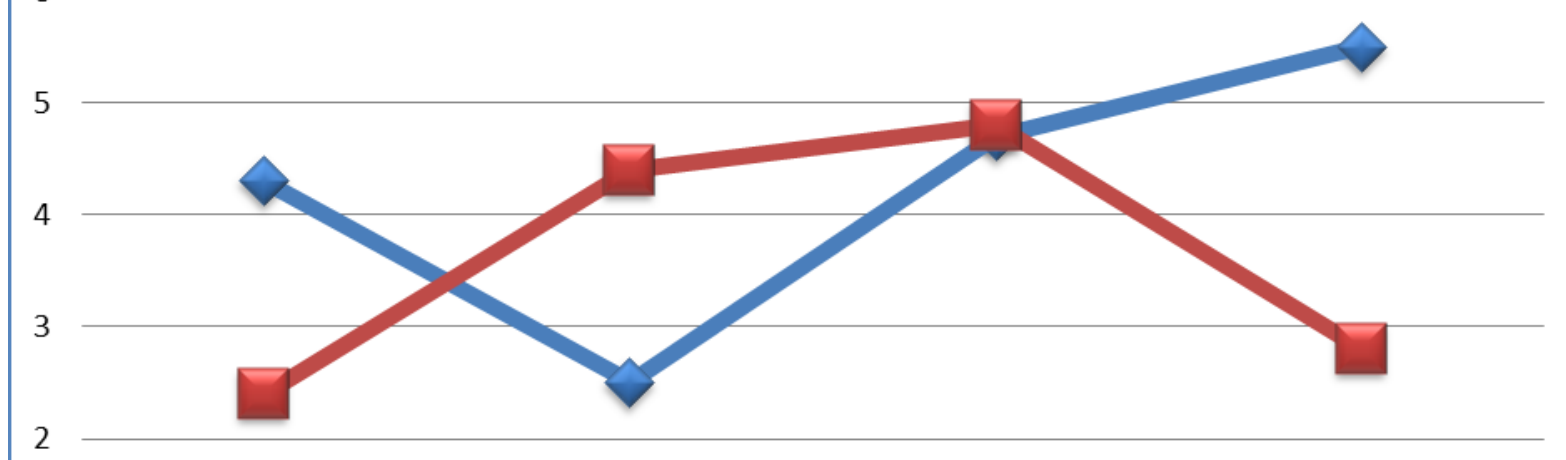

1

0
Reduce 1
Eliminate 2
Raise 3
Create 4

\section{Blue Ocean}

$\rightarrow$ Red Ocean

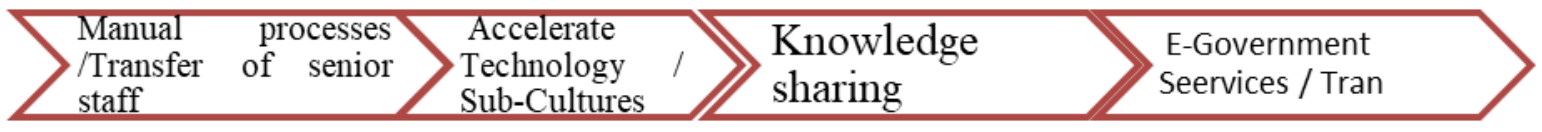

Figure 7. The newly constructed blue ocean strategy value curve for value innovation.

Source :by authors

The study recommend based on the blue ocean strategy, elimination of sub-cultures within the public organisations to promote collectiveness among workers. Knowledge sharing and knowledge management is necessary to spread technical abilities and expertise within the public sector. Indiscriminate transfers of senior staff from one public organisation to the other in way deplete knowledge and create gabs. Lastly, senior employees going on retirement whether voluntary or compulsory should do so after rigorous mentoring of new staff to take over from the outgoing ones in order to maintain consistency.

Acknowledgement

This research is supported by the National Natural Science Foundation of China (NSFC) under the grant; 71371087 and partly supported by Jiangsu University.

\section{Reference}

Adhikari, P., \& Gårseth, N. L. (2016). Implementing public sector accruals in OECD member states: Major issues and challenges. Accounting Forum, 40(2), 125-142. https://doi.org/10.1016/j.accfor.2016.02.001 
Ahmed, P. K., \& Rafiq, M. (2002). Case Study 10 - Lutheran Brotherhood: building skills and competencies through internal marketing Internal Marketing (pp. 255-257). Oxford: Butterworth-Heinemann.

Alzeban, A., \& Gwilliam, D. (2014). Factors affecting the internal audit effectiveness: A survey of the Saudi public sector. Journal of International Accounting, Auditing and Taxation, 23(2), 74-86. https://doi.org/10.1016/j.intaccaudtax.2014.06.001

Arundel, A., Casali, L., \& Hollanders, H. (2015). How European public sector agencies innovate: The use of bottom-up, policy-dependent and knowledge-scanning innovation methods. Research Policy, 44(7), 1271-1282. https://doi.org/10.1016/j.respol.2015.04.007

Ashraf, J., \& Uddin, S. (2016). New public management, cost savings and regressive effects: A case from a less developed country. Critical Perspectives on Accounting, 41, 18-33. https://doi.org/10.1016/j.cpa.2015.07.002

Azar, O. H. (2008). Blue Ocean Strategy: How to Create Uncontested Market Space and Make the Competition Irrelevant, W. Chan Kim, Renée Mauborgne. Harvard Business School Press (2005). Long Range Planning, 41(2), 226-228. https://doi.org/10.1016/j.lrp.2008.02.003

Aziz, M. A. A., Rahman, H. A., Alam, M. M., \& Said, J. (2015). Enhancement of the Accountability of Public Sectors through Integrity System, Internal Control System and Leadership Practices: A Review Study. Procedia Economics and Finance, 28, 163-169. https://doi.org/10.1016/S2212-5671(15)01096-5

Balabonienè, I., \& Večerskienè, G. (2015). The Aspects of Performance Measurement in Public Sector Organization. Procedia - Social and Behavioral Sciences, 213, 314-320. https://doi.org/10.1016/j.sbspro.2015.11.544

Baumgartner, R. J., \& Rauter, R. (2017). Strategic perspectives of corporate sustainability management to develop a sustainable organization. Journal of Cleaner Production, 140, Part 1, 81-92. https://doi.org/10.1016/j.jclepro.2016.04.146

Blok, V., Wesselink, R., Studynka, O., \& Kemp, R. (2015). Encouraging sustainability in the workplace: a survey on the pro-environmental behaviour of university employees. Journal of Cleaner Production, 106, 55-67. https://doi.org/10.1016/j.jclepro.2014.07.063

Boe, O., \& Kvalvik, Ø. (2015). Effective Use of Resources in the Public Management Sector in Norway. Procedia Economics and Finance, 26, 869-874. https://doi.org/10.1016/S2212-5671(15)00896-5

Cardy, R. L., \& Selvarajan, T. T. (2006). Competencies: Alternative frameworks for competitive advantage. Business Horizons, 49(3), 235-245. https://doi.org/10.1016/j.bushor.2005.09.004

Chan, K. W., \& Mauborgne, R. (2005). Blue Ocean Strategy: How to create uncontested market space and make the competition irrelevant. Harvard Business School Press, Boston, $M A$. 


\section{Macrothink}

Journal of Public Administration and Governance ISSN 2161-7104

Cohen, D. J. (2015). HR past, present and future: A call for consistent practices and a focus on competencies. Human Resource Management Review, 25(2), 205-215. https://doi.org/10.1016/j.hrmr.2015.01.006

Córdova, F. M., Durán, C., \& Galindo, R. (2014). Comparative Analysis of ICT in Public-private Systems: The OHIM Case in the European Union and the Internal Revenue System in Chile. Procedia Computer Science, 31, 95-104. https://doi.org/10.1016/j.procs.2014.05.249

De Bruecker, P., Van den Bergh, J., Beliën, J., \& Demeulemeester, E. (2015). Workforce planning incorporating skills: State of the art. European Journal of Operational Research, 243(1), 1-16. https://doi.org/10.1016/j.ejor.2014.10.038

De Magalhães, C., \& Freire, T. S. (2017). Contracting out publicness: The private management of the urban public realm and its implications. Progress in Planning, 115, 1-28. https://doi.org/10.1016/j.progress.2016.01.001

Elbanna, S. (2016). Managers' autonomy, strategic control, organizational politics and strategic planning effectiveness: An empirical investigation into missing links in the hotel sector. Tourism Management, 52, 210-220. https://doi.org/10.1016/j.tourman.2015.06.025

Farzin, M. R., Kahreh, M. S., Hesan, M., \& Khalouei, A. (2014). A Survey of Critical Success Factors for Strategic Knowledge Management Implementation: Applications for Service Sector. Procedia - Social and Behavioral Sciences, 109, 595-599. https://doi.org/10.1016/j.sbspro.2013.12.512

Gursoy, D., \& Swanger, N. (2007). Performance-enhancing internal strategic factors and competencies: Impacts on financial success. International Journal of Hospitality Management, 26(1), 213-227. https://doi.org/10.1016/j.ijhm.2006.01.004

Joyce, P. (2015). Strategic management in the public sector: Routledge.

Kim, W. C., \& Mauborgne, R. (2009). How strategy shapes structure. Harvard business review, 87(9), 72-80.

Kromidha, E., \& Córdoba, P. J. R. (2017). Discursive Institutionalism for reconciling change and stability in digital innovation public sector projects for development. Government Information Quarterly, 34(1), 16-25. https://doi.org/10.1016/j.giq.2016.11.004

Lapsley, I., \& Rekers, J. V. (2017). The relevance of strategic management accounting to popular culture: The world of West End Musicals. Management Accounting Research, 35, 47-55. https://doi.org/10.1016/j.mar.2017.01.001

Maresova, P., \& Kacetl, J. (2015). Cloud Computing in the Public Sector - Case Study in Educational Institution. Procedia - Social and Behavioral Sciences, 182, 341-348. https://doi.org/10.1016/j.sbspro.2015.04.781 


\section{MInstitute Machink $_{\text {Inthe }}$}

Journal of Public Administration and Governance ISSN 2161-7104

Matei, A., \& Drumasu, C. (2015). Corporate Governance and Public Sector Entities. Procedia Economics and Finance, 26, 495-504. https://doi.org/10.1016/S2212-5671(15)00879-5

Midin, M., Joseph, C., \& Mohamad, N. (2016). Advancing Sustainable Development in the Public Sector via Stakeholders' Engagement Disclosure Website. Procedia - Social and Behavioral Sciences, 224, 93-100. https://doi.org/10.1016/j.sbspro.2016.05.408

Omar, A., Weerakkody, V., \& Sivarajah, U. (2017). Digitally enabled service transformation in UK public sector: A case analysis of universal credit. International Journal of Information Management, 37(4), 350-356. https://doi.org/10.1016/j.ijinfomgt.2017.04.001

Ozkan, T. O., \& Basgoze, P. (2017). Pre-recovery emotions and satisfaction: A moderated mediation model of service recovery and reputation in the banking sector. European Management Journal, 35(3), 388-395. https://doi.org/10.1016/j.emj.2016.06.010

Scupola, A., \& Zanfei, A. (2016). Governance and innovation in public sector services: The case of the digital library. Government Information Quarterly, 33(2), 237-249. https://doi.org/10.1016/j.giq.2016.04.005

Sour, L. (2017). Progress in the quantity of financial information in the public sector in Mexico following the LGCG. Contaduría y Administración, 62(2), 442-460. https://doi.org/10.1016/j.cya.2017.02.002

Strategic management: Fred R. David, Prentice-Hall (1995), 5th Edn, 1084 pp., £21.95. (1995). Long Range Planning, 28(6), 116. https://doi.org/10.1016/0024-6301(95)91131-6

Sutheewasinnon, P., Hoque, Z., \& Nyamori, R. O. (2016). Development of a performance management system in the Thailand public sector: Isomorphism and the role and strategies of institutional entrepreneurs. Critical Perspectives on Accounting, 40, 26-44. https://doi.org/10.1016/j.cpa.2015.06.002

ter Bogt, H., \& Tillema, S. (2016). Accounting for trust and control: Public sector partnerships in the arts. Critical Perspectives on Accounting, 37, 5-23. https://doi.org/10.1016/j.cpa.2015.10.002

van Helden, J., \& Uddin, S. (2016). Public sector management accounting in emerging economies: A literature review. Critical Perspectives on Accounting, 41, 34-62. https://doi.org/10.1016/j.cpa.2016.01.001

Weerakkody, V., Omar, A., El-Haddadeh, R., \& Al-Busaidy, M. (2016). Digitally-enabled service transformation in the public sector: The lure of institutional pressure and strategic response towards change. Government Information Quarterly, 33(4), 658-668. https://doi.org/10.1016/j.giq.2016.06.006

Yapa, P. W. S. (2014). In whose interest? An examination of public sector governance in Brunei Darussalam. Critical Perspectives on Accounting, 25(8), 803-818. https://doi.org/10.1016/j.cpa.2014.03.003 


\section{Copyright Disclaimer}

Copyright for this article is retained by the author(s), with first publication rights granted to the journal.

This is an open-access article distributed under the terms and conditions of the Creative Commons Attribution license (http://creativecommons.org/licenses/by/4.0/). 